\title{
Electrodialysis of Phosphates in Industrial-Grade Phosphoric Acid
}

\author{
J. J. Machorro, ${ }^{1}$ J. C. Olvera, ${ }^{1}$ A. Larios, ${ }^{1}$ H. M. Hernández-Hernández, ${ }^{2}$ \\ M. E. Alcantara-Garduño, ${ }^{3}$ and G. Orozco ${ }^{1}$ \\ ${ }^{1}$ Centro de Investigación y Desarrollo Tecnológico en Electroquímica S.C. Parque, Tecnológico Querétaro, \\ 76703 Sanfandila Pedro Escobedo, QRO, Mexico \\ ${ }^{2}$ Universidad Tecnológica de Querétaro, 76148 Querétaro, QRO, Mexico \\ ${ }^{3}$ Universidad del Mar, Ciudad Universitaria, Puerto Ángel, 70902 Distrito de San Pedro Pochutla, OAX, Mexico
}

Correspondence should be addressed to G. Orozco; gorozco@cideteq.mx

Received 27 August 2013; Accepted 31 October 2013

Academic Editors: M. Barragán and H. Zhao

Copyright (C) 2013 J. J. Machorro et al. This is an open access article distributed under the Creative Commons Attribution License, which permits unrestricted use, distribution, and reproduction in any medium, provided the original work is properly cited.

The objective of this research was to study the purification of industrial-grade phosphoric acid $\left(\mathrm{P}_{2} \mathrm{O}_{5}\right)$ by conventional electrodialysis. The experiments were conducted using a three-compartment cell with anion and cation membranes, and industrial acid solution was introduced into the central compartment. The elemental analysis of the diluted solution indicated that the composition of magnesium, phosphates, and sodium was reduced in the central compartment. The ratios of the concentration of the ions and the phosphates were essentially unchanged by the process. Consequently, electrodialysis could not purify the acid in the central compartment, and the migration of phosphate ions to the anolyte produced a highly concentrated phosphoric acid solution containing sulfates and chlorides as impurities. However, the migration of the phosphate ions across the membrane consumed a large amount of energy. Detailed speciation diagrams were constructed in this study. These diagrams showed that metal-phosphate complexes were predominant in the industrial phosphoric acid solution. This result explains why the ratios of the concentrations of the ion metals and the phosphates did not change in the purification process. The energy consumed in the electrodialysis indicated that the metal-phosphate complexes were less mobile than the free-phosphate ions. The speciation diagrams explained the experimental results satisfactorily.

\section{Introduction}

The annual global phosphorus consumption is approximately 20,764 million metric tons [1]. Phosphoric acid and phosphate salts have several applications. For example, phosphoric acid fuel cells use liquid phosphoric acid as an electrolyte [2, 3]. Industrial-grade phosphoric acid is produced from phosphate rock and consequently has a high content of mineral impurities, which lower the acid quality for commercial use. This industrial-grade phosphoric acid $\left(52-54 \% \mathrm{P}_{2} \mathrm{O}_{5}\right)$ is also named as merchant-grade acid. Phosphoric acid purification is a major challenge, and a variety of methods have been used to eliminate the impurities in the industrial-grade phosphoric acid [4-18]. These methods which are described in the literature are enumerated in Table 1 . In addition, Table 2 shows electrodialysis process for concentrating industrialgrade phosphoric acid [19-27]. These studies in Table 2 provided more comprehensive and consistent information on the energy requirements for the process. Comparing these methods is very difficult for the following reasons: (a) there is a wide variation in the types of the impurities in industrial-grade acid because ores of similar grades can originate from different mines; (b) consequently, the studies investigated different metal impurities; (c) the studies were neither consisted nor complete in their description of the acid purity; and (d) the studies used dissimilar efficiency criteria. Therefore, the methods described in Table 1 cannot be ranked in terms of their relative efficacies. Nonetheless, 
TABLE 1: Studies of industrial-grade phosphoric acid purification.

\begin{tabular}{|c|c|c|}
\hline Process & Efficiency/energy requirements/power consumption (kWh/kg) & Reference \\
\hline $\begin{array}{l}\text { Selective } \\
\text { precipitation }\end{array}$ & $63 \%$ of $\mathrm{Pb}$ and As was precipitated from the phosphate solution. Purification was carried out at $49^{\circ} \mathrm{C}$ & {$[4]$} \\
\hline $\begin{array}{l}\text { Selective } \\
\text { precipitation }\end{array}$ & $\begin{array}{l}\mathrm{Mg} \text { was removed by mixing the crude acid with } \mathrm{SiF}_{6}{ }^{2-} \text { to form } \mathrm{MgSiF}_{6} \cdot 6 \mathrm{H}_{2} \mathrm{O} \text {. Also, } 25 \% \mathrm{Fe} \text { and } \\
10 \% \mathrm{Al} \text { were removed. Filtrate had } 0.37-0.51 \% \text { of } \mathrm{MgO} \text { in } 72 \% \mathrm{P}_{2} \mathrm{O}_{5} \text {. The temperatures range was } 20 \\
\text { to } 30^{\circ} \mathrm{C}\end{array}$ & {$[5]$} \\
\hline $\begin{array}{l}\text { Selective } \\
\text { precipitation }\end{array}$ & $\begin{array}{l}\text { Ammonia was added to crude acid. Iron precipitates as } \mathrm{Fe}_{3}\left(\mathrm{~K}, \mathrm{NH}_{4}\right) \mathrm{H}_{8}\left(\mathrm{PO}_{4}\right)_{6} \cdot \mathrm{H}_{2} \mathrm{O} \text {. The } \\
\text { concentrations of } \mathrm{Al}, \mathrm{Fe} \text {, and } \mathrm{Mg} \text { were decreased by ten times their initial values. The process was } \\
\text { continued for } 8 \mathrm{~h} \text { at } 70^{\circ} \mathrm{C}\end{array}$ & {$[6]$} \\
\hline Solvent extraction & $\begin{array}{l}\text { The purified acid contained between } 50 \text { and } 60 \% \text { phosphate and approximately } 1 \% \mathrm{SO}_{4}{ }^{-} \text {and } \\
0.2 \% \mathrm{~F}^{-} \text {. The concentration of the cation impurities was approximately } 0.2 \% \text {. Crude phosphoric acid } \\
\left(\mathrm{P}_{2} \mathrm{O}_{5} 52 \%\right) \text { was fed at rate of } 19.1 \mathrm{~mL} / \mathrm{min} \text { at temperature of } 65^{\circ} \mathrm{C} \text {. The process produced } 37.5 \% \\
\text { phosphoric acid, and the impurities were extracted by solvent extraction at } 110^{\circ} \mathrm{C}\end{array}$ & {$[7]$} \\
\hline Solvent extraction & $\begin{array}{l}\text { The process removed approximately } 95 \% \text { of } \mathrm{Cd} \text { after } 260 \mathrm{~h} \text { of operation. The method used three } \\
\text { hydraulic pumps, an extraction module }\left(1.4 \mathrm{~m}^{2}\right) \text {, and a back-extraction module at pressure of } 4 \mathrm{psi}\end{array}$ & {$[8]$} \\
\hline $\begin{array}{l}\text { Flotation and } \\
\text { selective } \\
\text { precipitation }\end{array}$ & $\begin{array}{l}95 \% \text { of the Cd and metals impurities }\left(M^{n+}\right) \text { were removed by neutralizing the solution to } \mathrm{pH} 1.4-2.0 \\
\text { and cooling it to } 5-40^{\circ} \mathrm{C} \text {. The metals were precipitated as metal xanthates }(\mathrm{MXan}) \text {. The xanthate } \\
\text { having the longest and most branched organic part produced the best results }\end{array}$ & {$[9]$} \\
\hline $\begin{array}{l}\text { Nanofiltration by } \\
\text { membranes }\end{array}$ & $\begin{array}{l}\text { The filtering process operated at a temperature of approximately }-1^{\circ} \mathrm{C} \text { to about } 30^{\circ} \mathrm{C} \text { and at a pressure } \\
\text { between } 600 \text { and } 1000 \text { psig. The feed solution was filtered through a nanofiltration membrane to } \\
\text { remove approximately } 90 \% \text { of the metal ion impurities }\end{array}$ & {$[10]$} \\
\hline Solvent extraction & $\begin{array}{l}\text { Resin impregnated with extractants was put into contact with phosphoric acid for } 24 \mathrm{~h} \text { using a } \\
\text { reciprocal shaker }(150 \mathrm{rpm}) \text { at } 25^{\circ} \mathrm{C} \text {. Solvent extraction removed approximately } 90 \% \text { of the Cd from } \\
\text { concentrated phosphoric acid solutions. The presence of cations strongly decreased the Cd removal } \\
\text { efficiency. }\end{array}$ & {$[11]$} \\
\hline $\begin{array}{l}\text { Reverse osmosis } \\
\text { and nanofiltration }\end{array}$ & $\begin{array}{l}\text { Nanofiltration was more efficient than reverse osmosis. The permeate flow was } 13.5 \mathrm{~L} / \mathrm{m}^{2} \mathrm{~h} \text { at } \\
1800 \text { psi. The acid permeation was } 46.3 \% \text {, and } 99.3 \% \text { of the cationic impurities were globally rejected. } \\
\text { The concentration of the impurities was reduced by approximately } 100 \text { times the initial value. } \\
\text { However, the acid concentration was reduced to half its original value. }\end{array}$ & {$[12]$} \\
\hline $\begin{array}{l}\text { Selective } \\
\text { precipitation }\end{array}$ & $\begin{array}{l}\text { This method produced an acid solution with an As concentration of less than } 1 \mathrm{ppm} \text {. The purification } \\
\text { method produced } \mathrm{P}_{2} \mathrm{O}_{5} \text { concentration of at least } 72.4 \% \text {. The temperatures range was } 130 \text { to } 150^{\circ} \mathrm{C} \text {. } \\
\text { Examples of the method produced concentrations of impurities in industrial } 84-85 \% \text { phosphoric } \\
\text { acid were as follows: } \mathrm{Fe}(0.2-1.6 \%), \mathrm{Cr}(0.1-0.8 \%), \mathrm{Ni}(0.1-0.6 \%), \mathrm{Mo}(<0.5 \%) \text {, and } \mathrm{Na}(0.1 \%)\end{array}$ & {$[13]$} \\
\hline $\begin{array}{l}\text { Nanofiltration by } \\
\text { membranes }\end{array}$ & $\begin{array}{l}\text { An } 8 \mathrm{M} \text { acid solution was filtrated at } 1000 \text { psi for different periods of time. For periods longer than } \\
120 \mathrm{~h} \text {, the rejection of impurities decayed considerably. The acid permeation at } 25^{\circ} \mathrm{C} \text { was } \\
\text { approximately } 90 \% \text { and the metal impurities' retention was approximately } 97 \%\end{array}$ & {$[14]$} \\
\hline Solvent extraction & $\begin{array}{l}\text { Phosphoric acid was purified using solvent mixtures at } 30^{\circ} \mathrm{C} \text {. The most efficient } \mathrm{P}_{2} \mathrm{O}_{5} \text { recovery was } \\
\text { obtained using } 55 \% \text { methyl isobutyl ketone and } 45 \% \text { tributyl phosphate. A phase diagram was } \\
\text { created for the ternary system of } \mathrm{H}_{3} \mathrm{PO}_{4} \text {-water-optimal phosphate solvent. The concentration of } \\
\text { impurities decreased } 1000 \text { times from their initial values. } \mathrm{Mg}^{2+} \text { purification was higher than that for } \\
\text { the other impurities }\end{array}$ & {$[15]$} \\
\hline $\begin{array}{l}\text { Complex } \\
\text { formation and } \\
\text { zeolites as } \\
\text { adsorbents }\end{array}$ & $\begin{array}{l}\text { Bentonite and potassium amyl xanthate were used to remove organic impurities and Fe from crude } \\
\text { phosphoric acid. The efficiency of potassium amyl xanthate in reducing the iron content was } 79.19 \% \\
\text { and was accompanied by a small decrease in the } \mathrm{P}_{2} \mathrm{O}_{5} \text { concentration. Bentonite clay was used to } \\
\text { remove the organic impurities. } \mathrm{Na}_{2} \mathrm{SiO}_{3} \text { and } \mathrm{Na}_{2} \mathrm{CO}_{3} \text { reduced the } \mathrm{F}^{-} \text {content at } 70^{\circ} \mathrm{C} \text { at a } \\
\text { defluorination efficiency of } 90.56 \% \text {. The } \mathrm{Fe} \text { content was reduced to } 0.52 \% \text { of its initial value at a } \mathrm{P}_{2} \mathrm{O}_{5} \\
\text { loss of } 3 \% \text {. Cd and Cu were removed at a } \mathrm{P}_{2} \mathrm{O}_{5} \text { loss of } 1.70 \% \text {. The Fe minimizing efficiency was } \\
10.95-52.38 \% \text { at the temperatures of } 25 \text { to } 70^{\circ} \mathrm{C}\end{array}$ & {$[16]$} \\
\hline $\begin{array}{l}\text { Selective } \\
\text { precipitation }\end{array}$ & $\begin{array}{l}\text { Precipitation occurred at } 60^{\circ} \mathrm{C} \text {. The process produced } 85 \% \text { acid with } 200 \mathrm{ppb} \text { of Sb. The impurities } \\
\text { were removed by adding } \mathrm{H}_{2} \mathrm{~S} \text {. However, the } \mathrm{S}_{2}^{-} \text {content was } 220 \mathrm{ppb}\end{array}$ & [17] \\
\hline Solvent extraction & $\begin{array}{l}\text { The phosphoric acid was purified using n-butanol, n-hexanol, and n-octanol. Octanol was the most } \\
\text { efficient alcohol. The final concentration of } \mathrm{H}_{3} \mathrm{PO}_{4} \text { was } 9.2 \mathrm{M} \text {. } 98 \% \text { of } \mathrm{F}^{-} \text {was removed and the final } \\
\text { concentration of Fe was } 10 \mathrm{ppm} \text {. The } \mathrm{Cu}, \mathrm{Cd}, \mathrm{Mn} \text {, and } \mathrm{Zn} \text { concentrations were too low to be } \\
\text { determined. The temperature }\left(5^{\circ} \mathrm{C} \text { and } 60^{\circ} \mathrm{C}\right) \text { had a small effect }\end{array}$ & {$[18]$} \\
\hline
\end{tabular}


TABLE 2: Electrodialysis (ED) studies of industrial phosphoric purification $\left(54 \% \mathrm{P}_{2} \mathrm{O}_{5}\right.$ or $\left.74.5 \% \mathrm{H}_{3} \mathrm{PO}_{4}\right)$.

\begin{tabular}{|c|c|c|}
\hline ED process characteristics & Energy & Reference \\
\hline $\begin{array}{l}\text { Phosphoric acid was concentrated using a combination of } \\
\text { apatite } \mathrm{Ca}_{5}(\mathrm{PO})_{3}(\mathrm{~F}, \mathrm{Cl}, \mathrm{OH}) \text { digestion by sulfuric acid and } \\
\text { aluminum production from alunite } \mathrm{KAl}_{3}\left(\mathrm{SO}_{4}\right)_{2}(\mathrm{OH})_{6} \text {. The } \\
\text { catholyte }\left(\mathrm{H}_{3} \mathrm{PO}_{4}\right) \text { was separated from the middle compartment } \\
\left(\mathrm{K}_{2} \mathrm{SO}_{4}\right) \text { by a CEM, and the anolyte (water) was separated by } \\
\text { AEM. The products were } \mathrm{KH}_{2} \mathrm{PO}_{4} \text { (catholyte), a diluted } \\
\text { solution of } \mathrm{K}_{2} \mathrm{SO}_{4} \text {, and } \mathrm{H}_{2} \mathrm{SO}_{4} \text { (anolyte) }\end{array}$ & $\begin{array}{l}\text { A cell voltage of } 6 \mathrm{~V} \text { and a current of } 4.5 \mathrm{~A} \text { were used. } \\
\text { The current efficiency was approximately } 96 \% \text {. } \\
\text { Electric power consumption was } 1.27 \mathrm{KWh} / \mathrm{Kg} \text { of } \\
\mathrm{P}_{2} \mathrm{O}_{5} \text { at } 2.5 \text { weight } \% \mathrm{P}_{2} \mathrm{O}_{5}\end{array}$ & [19] \\
\hline $\begin{array}{l}\text { This method concentrated phosphoric acid by ED using } \\
\text { membranes typically used to desalinate water. The stack } \\
\text { assembly consisted of } 20 \text { cell pairs sandwiched between two } \\
\text { electrode compartments. A CR- } 61 \text { cation-transfer membrane } \\
\text { and an AR-I03 anion-transfer membrane were used to } \\
\text { concentrate the acid from } 0.1 \text { to } 1.0 \mathrm{M} \text { by electrodialysis. The } \\
\text { diluted compartment was fed with } 0.10 \mathrm{M}, 0.20 \mathrm{M}, 0.29 \mathrm{M} \text {, and } \\
0.45 \mathrm{M} \text { reagent-grade acid solutions and the compartment } \\
\text { concentrate had } 1 \mathrm{M} \text { of industrial-grade acid }\end{array}$ & $\begin{array}{l}\text { The total effective membrane area was } 2300 \mathrm{~cm}^{2} \text {. The } \\
\text { electrical currents applied were } 8,10,12 \text {, and } 14 \mathrm{~A} \text {. } \\
\text { The voltages varied from } 10 \text { to } 43 \mathrm{~V} \text {. This method } \\
\text { concentrated reagent-grade } \mathrm{H}_{3} \mathrm{PO}_{4} \text { from } 0.1 \text { to } 1.0 \mathrm{M} \text {. } \\
\text { The energy requirements ranged from } 1.73 \text { to } \\
2.50 \mathrm{kWh} / \mathrm{Kg} \text { of } \mathrm{P}_{2} \mathrm{O}_{5}\end{array}$ & {$[20]$} \\
\hline $\begin{array}{l}\text { A cell }\left(13.3 \mathrm{~cm}^{2}\right) \text { was divided into two compartments by an } \\
\text { AEM. The cathode was graphite and the anode was platinized } \\
\text { titanium. The volume of the catholyte ( } 4.11 \mathrm{M} \text { industrial-grade } \\
\text { acid, supplemented by ammonium ions) was } 100 \mathrm{~cm}^{3} \text { and the } \\
\text { volume of the anolyte (pure } 1 \mathrm{M} \mathrm{H}_{3} \mathrm{PO}_{4} \text { ) was } 1000 \mathrm{~cm}^{3} \text {. The } \\
\text { impurities were retained in the catholyte compartment. In the } \\
\text { anolyte compartment, } \mathrm{H}_{3} \mathrm{PO}_{4} \text { was formed with the anions } \\
\text { crossing through the AEM and protons produced at the anode. } \\
\text { AEM ARA 17/10 from Solvay (France) and RAI } 5035 \text { from } \\
\text { Raipore (USA) were used }\end{array}$ & $\begin{array}{l}\text { A constant current of } 60 \mathrm{Am}^{-2} \text { was applied for } \\
90 \mathrm{~min} \text {. The acid concentration changed from } 1 \mathrm{M} \text { to } \\
4.11 \mathrm{M} \text { with a } 63 \% \text { of yield. A } 4 \mathrm{M} \text { acid solution was } \\
\text { obtained for a current efficiency of } 74 \% \text { in the } \\
\text { anolyte compartment. } \mathrm{Mg}, \mathrm{Al} \text {, and Fe were removed } \\
\text { at } 95-100 \% \text {. The efficiency was limited by the } \\
\text { migration of protons across the anion membrane } \\
\text { (proton leakage) }\end{array}$ & {$[21]$} \\
\hline $\begin{array}{l}\text { Cell with two compartments was divided by a membrane. The } \\
\text { catholyte was industrial phosphoric acid } 10 \text { to } 55 \% \text { percent } \mathrm{P}_{2} \mathrm{O}_{5} \\
\text { and anolyte was } 1 \text { to } 40 \% \mathrm{P}_{2} \mathrm{O}_{5}\end{array}$ & $\begin{array}{l}\text { The electrical current density ranges from } 100 \text { to } \\
3000\left(\mathrm{~A} / \mathrm{m}^{2}\right)\end{array}$ & {$[22]$} \\
\hline $\begin{array}{l}\text { An electrodeionization cell }\left(36 \mathrm{~cm}^{2}\right) \text { with a central } \\
\left.\text { compartment (industrial } 11 \% \mathrm{P}_{2} \mathrm{O}_{5} \text { or } 15.2 \% \mathrm{H}_{3} \mathrm{PO}_{4}\right) \text { was } \\
\text { delimited by AEM/textile membrane and } \mathrm{CEM} / \text { textile } \\
\text { membrane. Catholyte and anolyte were } 2 \mathrm{M} \mathrm{H}_{3} \mathrm{PO}_{4} \text { solutions } \\
\text { placed in the other compartments }\end{array}$ & $\begin{array}{l}\text { Very low current efficiencies for both cations and } \\
\text { anions were observed after } 5 \mathrm{~h} \text { of treatment. This } \\
\text { method produced } 11 \% \text { phosphoric acid with low } \\
\text { concentrations of impurities: } \mathrm{Mg}\left(1.4 \mathrm{gdm}^{-3}\right), \mathrm{Fe} \\
\left(0.9 \mathrm{gdm}^{-3}\right), \mathrm{Zn}\left(0.4 \mathrm{gdm}^{-3}\right), \mathrm{Cd}\left(0.01 \mathrm{gdm}^{-3}\right) \text {, and } \\
\mathrm{SO}_{4}{ }^{2-}\left(16.5 \mathrm{gdm}^{-3}\right) \text {. The highest current efficiency } \\
\text { for cations was found for } \mathrm{Mg}^{2+}\end{array}$ & [23] \\
\hline
\end{tabular}

Cell with liquid membrane of amyl alcohol with the addition of a trialkylamine. The catholyte was $\mathrm{H}_{3} \mathrm{PO}_{4} 1.0 \mathrm{M}$ and anolyte was $\mathrm{H}_{2} \mathrm{O}$. The cathode was made of stainless steel and anode was made of platinum or titanium coated with ruthenium dioxide

Extraction of phosphate ions from the starting solution was $95 \%$

The raw material was $\mathrm{H}_{3} \mathrm{PO}_{4}$ containing mainly calcium phosphate. A low concentration of acid was fed into alternate partition chambers formed cation transfer membranes. $\mathrm{H}_{3} \mathrm{PO}_{4}$ was introduced on the anode sides of the partition chambers. No data Process is carried out under acidic conditions, avoiding precipitates of the impurities such as iron and aluminum Cells with a large number of anion and cation membranes were alternately arranged. Industrial phosphoric acid and diluted pure phosphoric acid $\left(10-44 \% \mathrm{P}_{2} \mathrm{O}_{5}\right)$ were supplied to the anode and to the cathode compartments, respectively

Electro-electrodialysis with laboratory-scale cell. The cathode was graphite and the anode was platinized titanium. There were three compartments divided by anionic and cationic membranes. The industrial $\mathrm{H}_{3} \mathrm{PO}_{4}$ was introduced into the central compartment
The current density was $100-2000 \mathrm{~A} / \mathrm{m}^{2}$. The energy requirement ranged from 3.95 to $15.78 \mathrm{kWh} / \mathrm{Kg}$ of $\mathrm{P}_{2} \mathrm{O}_{5}$

The cell voltage was $4 \mathrm{~V}$ and current of $10 \mathrm{~A}$. A $28 \%$ $\mathrm{H}_{3} \mathrm{PO}_{4}$ was removed from central compartment and impurities decrease. Also, Food-grade $\mathrm{H}_{3} \mathrm{PO}_{4}$ at $25 \%$ was produced in anolyte after $21 \mathrm{~h}$ at $3-4 \mathrm{~V}$ and $11 \mathrm{~A}$ 
the studies of electrodialysis show that concentrated phosphoric acid with a low concentration of metal impurities can be obtained by electrodialysis; see Table 2 .

Table 1 serves to display the great importance of the acid purification. Although a variety of problem-solving techniques have been identified, there are a limited number of studies with acceptable results. The production of food-grade phosphoric acid is a difficult business.

A significant factor for elucidating the purification process is the speciation of the metals in the concentrated acids. However, the studies presented in Tables 1 and 2 do not address this issue. Therefore, in this study, speciation diagrams were constructed to more thoroughly analyze the purification process.

The goal of this work is to evaluate the viability of electrodialysis for the production of high-value chemicals from raw materials that are abundant in the central region of Mexico and therefore these would be feasible resources for mass production. Other studies are also being conducted in our laboratory on a different highly pure raw material. The current study will serve as an important benchmark for our future research.

\section{Materials and Methods}

2.1. Materials and Reagents. Two samples of industrial-grade phosphoric acid (also called wet-industrial phosphoric acid) were obtained from Fertinal S. A. (Mexico). These raw materials were produced by the acid digestion of phosphate rock. Pure phosphoric acid 86\% was purchased from J. T. Baker (ACS Grade). All other reagents were of analytical grade and were obtained from commercial sources and used without further purification. The high ionic strength of industrial phosphoric acid can produce a layer of precipitates of metalphosphates, metal-sulfates, and so forth, on the membrane surface. Thus, a dilution solution of industrial acid at 5\% w/w was used to prevent membrane fouling.

A trace element mineral analysis was performed by inductively coupled plasma mass spectrometry (Perkin Elmer, USA, model Optima 3300 DV) and by flame atomic absorption spectrophotometry (Perkin Elmer, USA, model AAnalyst 200). The presence of sulfate, fluoride, and phosphate was identified by UV-Vis spectrometry. Samples taken from a phosphoric acid production site were analyzed by potentiometric titration with a $\mathrm{NaOH}$ solution.

The membranes were purchased from Ameridia (the US representative of Tokuyama Corporation, Japan). The main characteristic of these membranes is their excellent exchange capacity (mequiv $\mathrm{g}^{-1}$ of ion in the dry membrane form). An AMX-Neosepta anion exchange membrane was used with an exchange capacity of 1.25 mequiv $^{-1}$. A CMX-Neosepta cation exchange membrane was used with an exchange capacity 1.62 mequiv $^{-1}$. Neosepta-AMX contains quaternary ammonium groups as fixed charges, and Neosepta-CMX contains sulfonic acid groups as fixed charges [28]. These membranes were equilibrated with $1 \mathrm{M} \mathrm{KCl}$ solution for $12 \mathrm{~h}$ before each experiment.
2.2. Speciation Calculations. The speciation diagrams predict the value of $\alpha$, the fraction of ions that are free or associated, at a given $\mathrm{pH}$ value. The dissociation equilibrium for the phosphate-containing species in the diagrams is given by

$$
\begin{gathered}
\mathrm{H}_{3} \mathrm{PO}_{4}{ }^{0} \longleftrightarrow \mathrm{H}^{+}+\mathrm{H}_{2} \mathrm{PO}_{4}{ }^{-} \\
K_{1}=\frac{\left[\mathrm{H}^{+}\right]\left[\mathrm{H}_{2} \mathrm{PO}_{4}{ }^{-}\right]}{\left[\mathrm{H}_{3} \mathrm{PO}_{4}{ }^{0}\right]} \\
\mathrm{H}_{2} \mathrm{PO}_{4}{ }^{-} \longleftrightarrow \mathrm{H}^{+}+\mathrm{HPO}_{4}{ }^{2-} \quad K_{2}=\frac{\left[\mathrm{H}^{+}\right]\left[\mathrm{HPO}_{4}{ }^{4-}\right]}{\left[\mathrm{H}_{2} \mathrm{PO}_{4}{ }^{-}\right]} \\
\mathrm{HPO}_{4}{ }^{2-} \longleftrightarrow \mathrm{H}^{+}+\mathrm{PO}_{4}{ }^{3-} \quad K_{3}=\frac{\left[\mathrm{H}^{+}\right]\left[\mathrm{PO}_{4}{ }^{3-}\right]}{\left[\mathrm{HPO}_{4}{ }^{2-}\right]} .
\end{gathered}
$$

The $\mathrm{HA}$ acids were $\mathrm{HF}, \mathrm{HCl}$, and $\mathrm{H}_{2} \mathrm{SO}_{4}$, and the respective anions were $\mathrm{F}^{-}, \mathrm{Cl}^{-}, \mathrm{HSO}_{4}{ }^{-}$, and $\mathrm{SO}_{4}{ }^{2-}$. The general dissociation acid reaction is given by

$$
\mathrm{HA} \longleftrightarrow \mathrm{H}^{+}+\mathrm{A}^{-} \quad K_{4}=\frac{\left[\mathrm{H}^{+}\right]\left[\mathrm{A}^{-}\right]}{[\mathrm{HA}]} .
$$

Note that the silicon concentration is related to the fluoride concentration. That is, during industrial phosphoric acid production, fluoride is produced in the form of fluorosilicic acid. However, this acid and the $\mathrm{SiF}_{6}{ }^{2-}$ ion dissociate into $\mathrm{Si}(\mathrm{HO})_{4}$ and $\mathrm{HF}$. The dissociation reactions are as follows:

$$
\begin{gathered}
\mathrm{H}_{2} \mathrm{SiF}_{6} \longrightarrow 2 \mathrm{H}^{+}+\mathrm{SiF}_{6}{ }^{2-} \\
\mathrm{SiF}_{6}{ }^{2-}+4 \mathrm{H}_{2} \mathrm{O} \longrightarrow 4 \mathrm{H}^{+}+\mathrm{Si}(\mathrm{HO})_{4}+6 \mathrm{~F}^{-} \\
\mathrm{F}^{-}+\mathrm{H}^{+} \longrightarrow \mathrm{HF} .
\end{gathered}
$$

Therefore, $\mathrm{Si}(\mathrm{HO})_{4}$ and $\mathrm{SiF}_{6}{ }^{2-}$ were also included in the speciation diagrams. In addition, 18 metal-phosphate complexes or ion-pairs, that is, $\mathrm{NaHPO}_{4}{ }^{-}, \mathrm{AlHPO}_{4}{ }^{+}$, and so forth, were included with their respective simple cations, that is, $\mathrm{Na}^{+}, \mathrm{Al}^{3+}$, and so forth. The general equation of the chemical equilibrium for the metal-phosphate complexes is

$$
\begin{aligned}
& \mathrm{MH}_{x} \mathrm{PO}_{4}{ }^{n+x-3} \longleftrightarrow \mathrm{M}^{n}+\mathrm{H}_{x} \mathrm{PO}_{4}{ }^{x-3} \\
& K_{5}=\frac{\left[\mathrm{M}^{n}\right]\left[\mathrm{H}_{x} \mathrm{PO}_{4}{ }^{x-3}\right]}{\left[\mathrm{MH}_{x} \mathrm{PO}_{4}{ }^{n+x-3}\right]}
\end{aligned}
$$

where $x$ equals 1,2 , or 3 , depending on the partial deprotonation of the phosphoric acid and $n$ can vary between 1 and 3 . Values derived from the literature [29-31] were used for the equilibrium constants $K_{1}$ to $K_{5}$. The quantity $\alpha$ is defined by the following equation:

$$
\alpha_{\mathrm{A}}=\frac{[\mathrm{A}]}{C_{t}},
$$

where [A] is the concentration of species $\mathrm{A}$ and $C_{t}$ is the total concentration of all the species that contain A. Material 
balances must be formulated to determine the fraction $\alpha$. The total quantities of the metal impurities $\left(M_{t}\right)$, the acids $\left(C_{\mathrm{H}_{n} \mathrm{~A}}\right)$, and the phosphates $\left(P_{t}\right)$ are fixed in a closed system; therefore, the following set of equations holds:

$$
\begin{gathered}
P_{t}=\left[\mathrm{H}_{3} \mathrm{PO}_{4}{ }^{0}\right]+\left[\mathrm{H}_{2} \mathrm{PO}_{4}{ }^{-}\right]+\left[\mathrm{HPO}_{4}{ }^{2-}\right]+\left[\mathrm{PO}_{4}{ }^{3-}\right] \\
M_{t}=\left[\mathrm{M}^{+}\right]+\left[\mathrm{MH}_{2} \mathrm{PO}_{4}{ }^{0}\right]+\left[\mathrm{MHPO}_{4}{ }^{-}\right]+\left[\mathrm{MPO}_{4}{ }^{2-}\right] \\
C_{\mathrm{H}_{n} \mathrm{~A}}=\left[\mathrm{H}_{n} \mathrm{~A}\right]+\left[\mathrm{H}_{n-1} \mathrm{~A}^{-}\right]+\cdots+\left[\mathrm{A}^{-}\right]
\end{gathered}
$$

Equations (10), (11) or (12) can be combined with the equilibrium constants (1)-(5) and (8) and (9) to obtain a set of $\alpha$-fractions as functions of $\left[\mathrm{H}^{+}\right]$. The $\alpha$-fraction for the $\mathrm{H}_{x} \mathrm{PO}_{4}{ }^{x-3}$ species is defined by the following equation:

$$
\begin{aligned}
\alpha_{\mathrm{H}_{x} \mathrm{PO}_{4}{ }^{x-3}} & =\frac{\left[\mathrm{H}_{x} \mathrm{PO}_{4}{ }^{x-3}\right]}{P_{t}} \\
& =\frac{1}{\left[\mathrm{H}^{+}\right]^{n}+\left[\mathrm{H}^{+}\right]^{n-1} / K_{1}+\left[\mathrm{H}^{+}\right]^{n-2} / K_{1} K_{2}+\cdots},
\end{aligned}
$$

where $\left[\mathrm{H}^{+}\right]$denotes the proton concentration which was related to the $\mathrm{pH}$ and $K_{n}$ denotes the equilibrium constants $K_{1}$ to $K_{3}$. The $\alpha$-fractions of the metal-phosphate complexes were directly related to the $\alpha$-fraction of $\mathrm{H}_{x} \mathrm{PO}_{4}{ }^{x-3}$ species and their equilibrium constants; for example

$$
\begin{aligned}
& \alpha_{\mathrm{Ca}^{2+}}=\frac{\left[\mathrm{Ca}^{2+}\right]}{M_{t}} \\
&=1 \times\left(1+\frac{\alpha_{\mathrm{PO}_{4}{ }^{3-}}}{10^{-6.5}}+\frac{\alpha_{\mathrm{HPO}_{4}{ }^{2-}}}{10^{-2.7}}\right. \\
&\left.+\frac{\alpha_{\mathrm{H}_{2} \mathrm{PO}_{4}{ }^{-}}}{10^{-1.4}}\right)^{-1} .
\end{aligned}
$$

The speciation diagrams were calculated for solutions at $25^{\circ} \mathrm{C}$ and zero ionic strength. The ionic strength varied during the experiments; however, the equilibrium constants have been reported to depend weakly on the ionic strength $(0.40 /$ value $)$ [32]. The temperature increased by $10^{\circ} \mathrm{C}$ during the experiments. However, only a small variation with temperature has been reported for the equilibrium constants for complex formation $(0.045 / \mathrm{deg})$ [32]. Thus, the concentration fractions in diagrams were representative of the actual values.

2.3. Experimental Apparatus. The system consisted of an electrodialysis cell from Asahi Glass Co., DS-0 (Japan), three storage tanks, three hydraulic pumps and a DC power source. The electrodes (each with an effective area of $0.02 \mathrm{~m}^{2}$ ) were made of titanium coated with platinum and stainless steel. The solution flowed through a plastic schedule 40 polyvinyl chloride pipe. Hydraulic pumps, propelled the electrolyte solution from the storage tank to the electrodialysis cell, through the pipe and back to the storage tanks. A bypass was introduced to control the flow rate (at $5 \mathrm{~L} / \mathrm{min}$ ) at each inlet.
TABLE 3: Average composition of two industrial phosphoric acid samples.

\begin{tabular}{lcc}
\hline Species & Concentration & Milliequivalents of solute per liter \\
\hline $\mathrm{P}_{2} \mathrm{O}_{5}$ & $54 \% \mathrm{w} / \mathrm{w}$ & - \\
$\mathrm{SO}_{4}{ }^{2-}$ & $13.4480 \mathrm{~g} / \mathrm{L}$ & $(-) 274.0$ \\
$\mathrm{CaO}$ & $8.4116 \mathrm{~g} / \mathrm{L}$ & $(+) 299.9$ \\
$\mathrm{SiO}_{2}$ & $18.0240 \mathrm{~g} / \mathrm{L}$ & $\left(\mathrm{SiO}_{4}{ }^{4-}\right)(-) 1199.9$ \\
$\mathrm{Fe}_{2} \mathrm{O}_{3}$ & $7.9843 \mathrm{~g} / \mathrm{L}$ & $(+) 149.9$ \\
$\mathrm{Al}_{2} \mathrm{O}_{3}$ & $8.1567 \mathrm{~g} / \mathrm{L}$ & $(+) 239.9$ \\
$\mathrm{MgO}$ & $4.8364 \mathrm{~g} / \mathrm{L}$ & $(+) 239.9$ \\
$\mathrm{Na}_{2} \mathrm{O}$ & $3.0989 \mathrm{~g} / \mathrm{L}$ & $(+) 99.9$ \\
$\mathrm{~K}_{2} \mathrm{O}$ & $3.7678 \mathrm{~g} / \mathrm{L}$ & $(+) 79.9$ \\
$\mathrm{HF}$ & $3.4196 \mathrm{~g} / \mathrm{L}$ & $(-) 170.9$ \\
$\mathrm{HCl}$ & $0.1773 \mathrm{~g} / \mathrm{L}$ & $(-) 93.7$ \\
\hline
\end{tabular}

The phosphoric acid concentration is typically expressed in terms of the $\mathrm{P}_{2} \mathrm{O}_{5}$ concentration. The conversion formula is as follows: $\left[\mathrm{H}_{3} \mathrm{PO}_{4}\right]=\left[\mathrm{P}_{2} \mathrm{O}_{5}\right] \times$ $196 / 142$. Thus, $54 \% \mathrm{P}_{2} \mathrm{O}_{5}$ concentration corresponds to an acid concentration of $74.5 \%$.

Figure 1 is a schematic of the experimental apparatus for phosphoric acid demineralization. The two membranes were separated by $1.5 \mathrm{~mm}$, and the gap in the anolyte and the catholyte compartments was $2.25 \mathrm{~mm}$.

Prior to each experiment, the three compartments were fed with a $0.01 \mathrm{M} \mathrm{NaCl}$ solution (for $30 \mathrm{~min}$ ), which was replaced a posteriori with the respective solutions (for $30 \mathrm{~min}$ ), and finally with fresh solutions for demineralization. The central compartment was filled with the solutions shown in Figure 1. Then, the central compartment contained a $0.1 \mathrm{M} \mathrm{NaCl}$ solution in $5 \% \mathrm{w} / \mathrm{w}$ analytical-grade phosphoric acid. Also, solutions of $5 \% \mathrm{w} / \mathrm{w}$ industrial-grade acid were introduced into the central compartment, and the behavior of the solutions was compared.

The current-voltage curves were obtained in a galvanodynamic mode, and the limiting current density was obtained from the electrical resistance (R) versus 1/electrical current (I) plots, as described by Sorensen [33]. The temperature, the conductivity, the flow rate, the electrical voltage, and the electrical current were measured during the experiments. More details of the apparatus are provided in our previous work [34]. The Toroidal Conductivity Sensor (Model 226, Rosemount Analytical, USA) was calibrated with $\mathrm{KCl}$ solutions. The experiments were performed in triplicate.

\section{Results}

3.1. Speciation Diagrams. The industrial-grade phosphoric acid was chemically analyzed for eleven components (see Table 3). The concentration of the impurities was $71.33 \mathrm{~g} / \mathrm{L}$, which was representative of the raw material produced by Fertinal (Mexico). The $\mathrm{pH}$ of the industrial phosphoric acid was approximately 1 ; consequently, the speciation diagrams (Figure 2) were concentrated in the acidic region.

During the manufacture of industrial-grade phosphoric acid by treating the rock with acids, fluoride was volatilized and lost in the residues and approximately $3 \mathrm{~g} / \mathrm{L}$ of fluoride remains in the phosphoric acid. Figure 2(a) shows that 


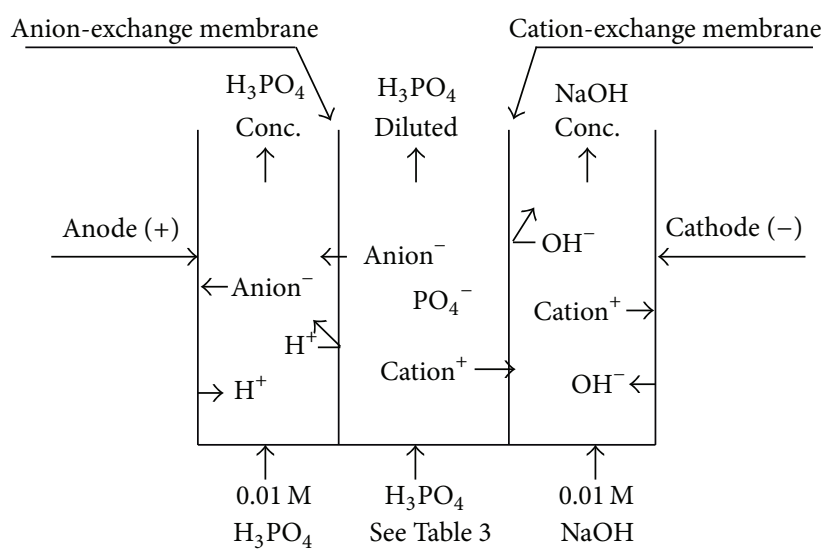

(a)

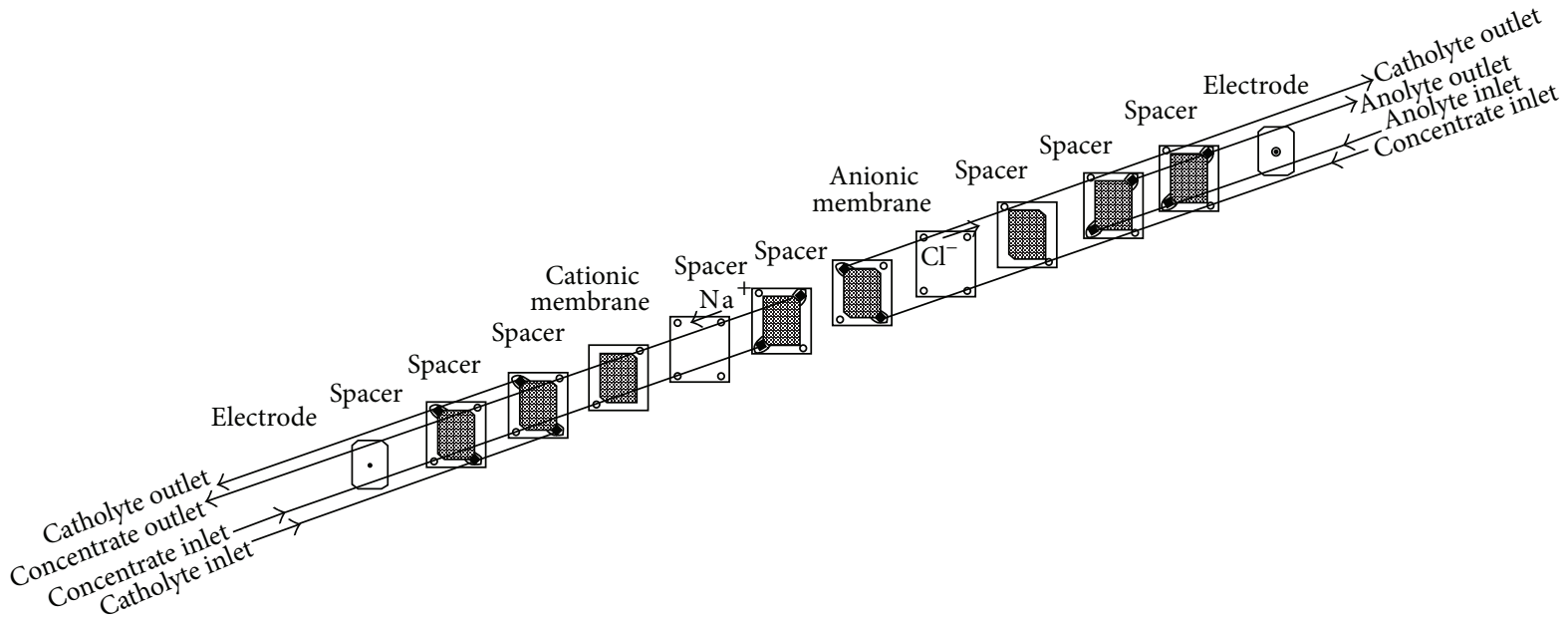

(b)

FIGURE 1: (a) Schematic of phosphoric acid demineralization apparatus, (b) classical electrodialysis; cation-exchange and anion-exchange membranes, fed solutions and products.

hydrogen fluoride $(\mathrm{HF})$ and siliceous acid $\mathrm{Si}(\mathrm{OH})_{4}$ were the predominant species in the industrial acid. The speciation diagrams show that electrodialysis cannot be used to remove fluoride and silicon because the Coulombic attraction was lowered considerably. To be precise, electrodialysis only can remove ionic impurities from industrial acid by using an electric current to pull these ions across the membrane. For HF and $\mathrm{Si}(\mathrm{OH})_{4}$, there is no net driving Coulombic force to produce a migration; that is, nonionic compounds did not migrate when an electric field was imposed. Figure 2(b) shows eight negatively charged species; however, only two ions (sulfates and chlorides) have high concentrations. Therefore, elevated migration can only be expected for these ions. Figure 2(c) shows the seven positively charged species in the $\mathrm{pH}$ region that was studied. However, only a few ionic species $\left(\mathrm{K}^{+}, \mathrm{Na}^{+}\right.$, and $\left.\mathrm{Mg}^{2+}\right)$ have high concentrations and consequently will migrate abundantly. Moreover, only about $40 \%$ of $\mathrm{Ca}^{2+}$ ions can migrate. Figures $2(\mathrm{~d})$ and 2(e) predict that metal-phosphate complexes or ion-pairs, such as $\mathrm{FeHPO}_{4}{ }^{+}$, can form for most metal impurities. Although included in the mathematical analysis, the amounts of the ion-pairs of sodium or potassium were always negligible in our solutions, for example, $\mathrm{NaPO}_{4}{ }^{2-}$; see Figure 2(f). Migneault and Forcé [35] and Pethybridge et al. [36] found lower ion-pair association constants of sodium or potassium.

These complexes or ion-pairs are essentially larger ions with lower effective electric charge density. The implication of this lower charge is an increase in the electrical resistance; to be precise, their positive charges allow the complexes to migrate near to the membrane, when electric field is applied across the cell. However, their large size prevents their passage abundantly through the membrane. Consequently, these charged molecules tend to accumulate on the dilute side of membrane and result in a buildup of membrane electrical resistance.

The industrial-grade phosphate had high concentration of phosphate and consequently the metal-phosphate complexes and ion-pairs were formed copiously. However, the studies presented in Table 1 did not address this issue because the speciation diagrams were not consulted. The implication of this is that studies cannot comprehensively analyze their purification process. On the other hand, the construction of 


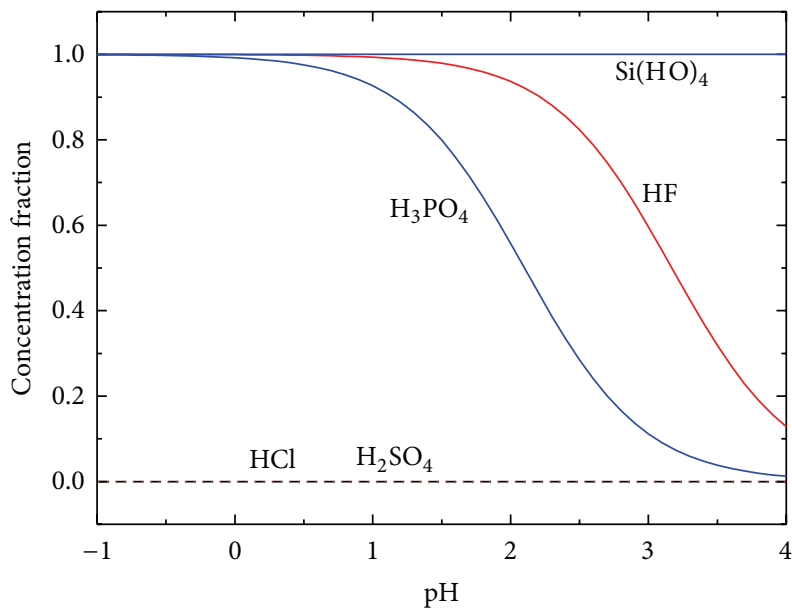

(a)

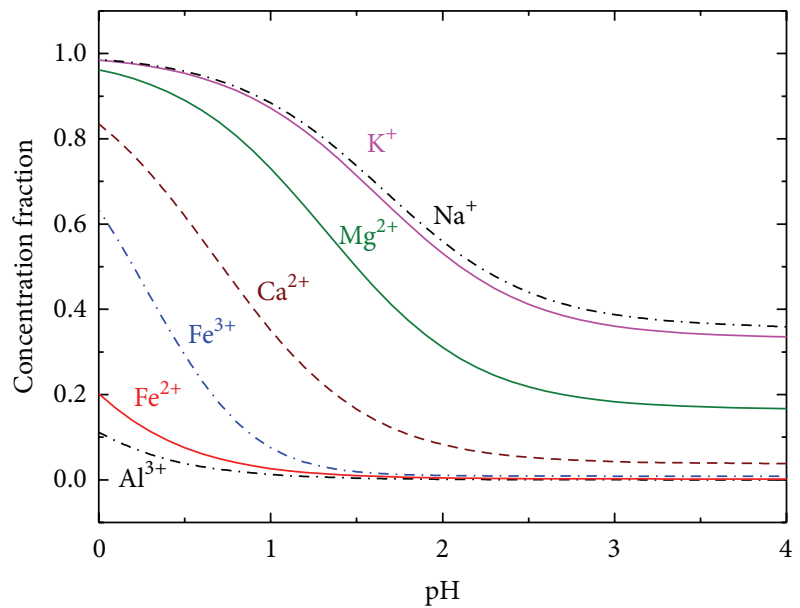

(c)

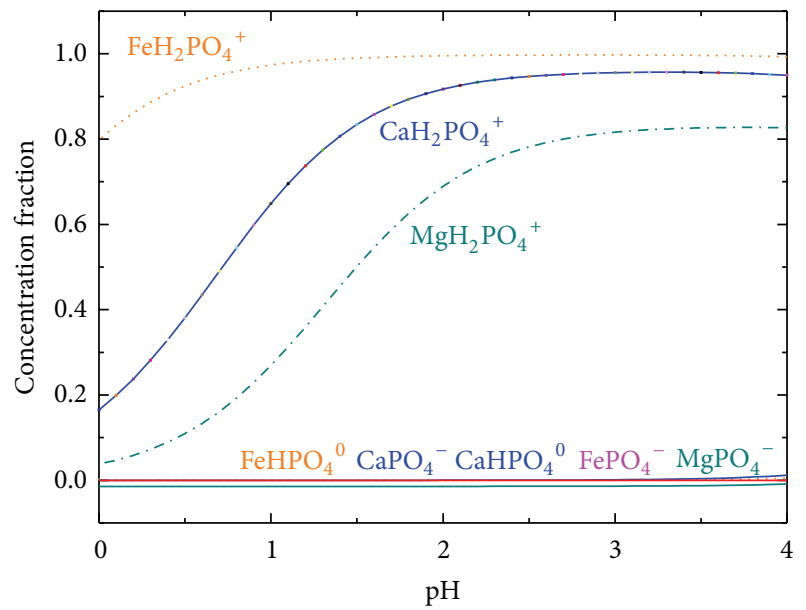

(e)

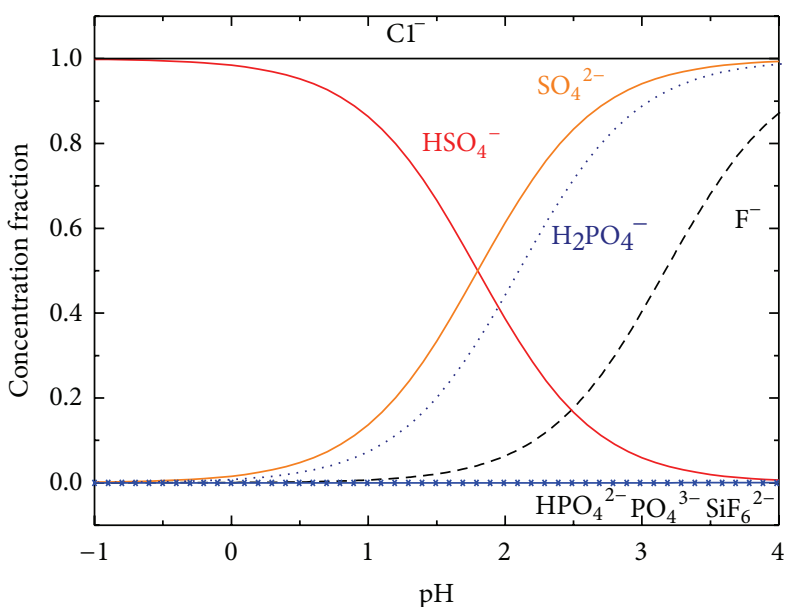

(b)

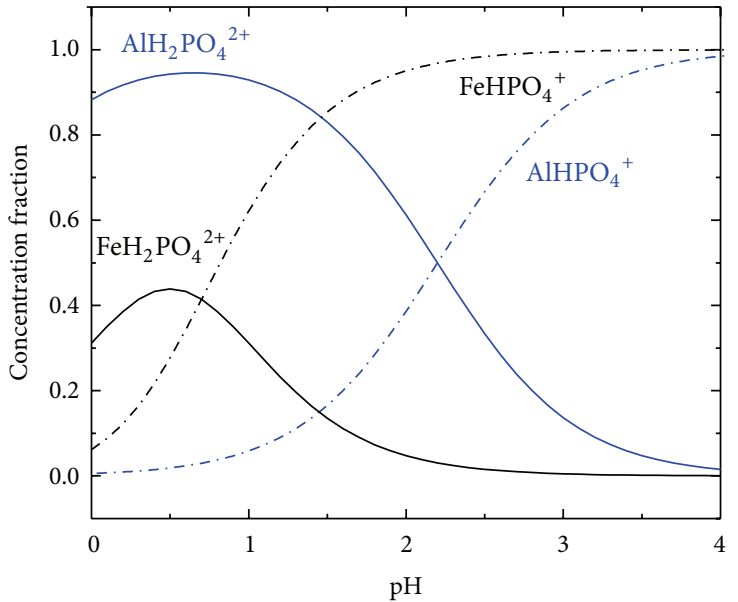

(d)

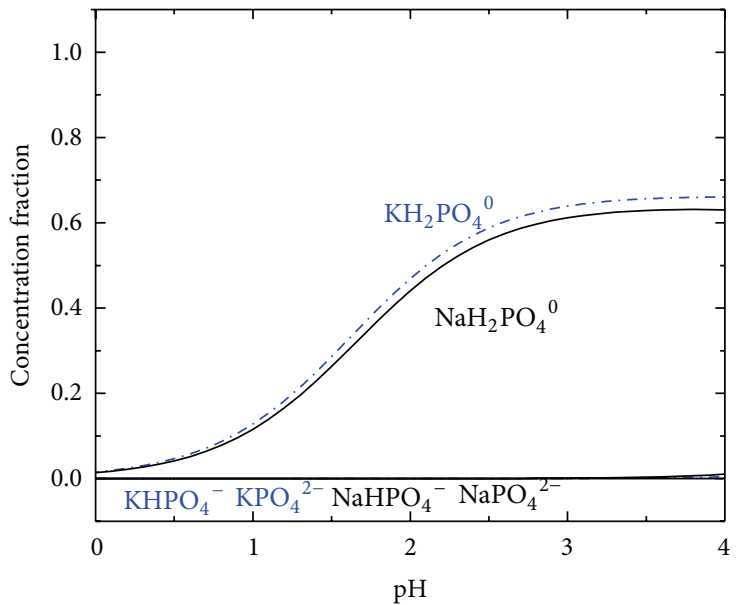

(f)

FIGURE 2: Speciation diagrams for (a) acids; (b) anions; (c) cations; (d) phosphate-metal (III) complexes; (e) phosphate-metal (II) complexes; and (f) phosphate-metal (I) complexes. 
the speciation diagrams implied very time-consuming calculations. However, there are software can easily constructed the diagrams. For example MEDUSA with its thermodynamic constants database HYDRA [37] is able to draw the diagrams. The database HYDRA is incomplete for the metal-phosphate complexes and ion-pairs constant, but it is possible added data. The diagrams constructed using the software MEDUSA and our diagrams were compared. The results are not shown for the sake of brevity. The computational software can be applied to create efficiently the speciation diagrams.

Azaroual et al. [38] recently show preliminary results for quantifying the undesirable mineral impurities from phosphate ores using a computation tool (SCALE2000 software). However, it is not possible yet to compare the estimated diagrams of aqueous speciation of phosphoric acid.

Figure 3 shows that the conductance of the industrial phosphoric acid was higher than that of the analytical-grade acid. The low conductivity of the pure acid was because the $\mathrm{H}_{2} \mathrm{PO}_{4}{ }^{-}$ion comprised only $6 \%$ of the phosphate concentration. However, the conductance of the industrial acid was related to the high ion concentration. The industrial phosphoric acid viscosity has also been reported to increase with the phosphoric acid concentration [39]. Note that pure $\mathrm{H}_{3} \mathrm{PO}_{4}$ consists of tetragonal groups that are linked by hydrogen bonds [40]. This structure results in a high viscosity fluid, especially at high phosphoric acid concentrations. The dimeric anion $\left(\mathrm{H}_{5} \mathrm{P}_{2} \mathrm{O}_{8}{ }^{-}\right)$has been found at high acid concentrations, but has not been observed in dilute solutions at room temperature $[41,42]$. For solutions below $50 \%$ phosphoric acid, there are more bonds between the phosphate ions and water than between the phosphate ions themselves [40]. These larger anions pass scarcely through the positively charged anion exchange membrane. Therefore, electrodialysis was conducted in dilute acid solutions to prevent the formation of phosphate dimeric anions.

3.2. Limiting Current Densities. The limiting current densities (Table 4) were obtained from the current-potential curves (Figure 4). These limiting currents were obtained directly from plots of the electrical resistance versus the reciprocal of the electrical current (which are not shown for brevity), using a method that has been described elsewhere [33, 34]. The inflexion point in the curve for the solution of $\mathrm{NaCl}$ in the analytical-grade acid was produced at steady state; that is, the numbers of ions entering the membrane equaled the number of ions entering the diffusion zone. The limiting currents of the industrial-grade phosphoric acid were difficult to obtain, whereas the limiting currents of the analytical-grade acid solutions were straightforward to determine. In addition, the limiting current was also selected to avoid damage to the membrane. Therefore, the limiting current values for the solutions of $\mathrm{NaCl}$ in analytical-grade phosphoric acid were selected for the electrodialysis of the industrial-grade phosphoric acid. These current-potential behaviors were affected by the electrical resistance of the electrodialysis cell, which was given by the sum of the solution and membrane resistances. In addition, the formation of the polarization layers adjacent to both sides of the membranes produced a great contribution to the electrical resistance of the cell.
TABLE 4: Limiting currents of the experimental three-compartment electrodialysis cells; dilute, central compartment: experimental solution; anolyte: $0.01 \mathrm{M} \mathrm{HCl}$; catholyte: $0.01 \mathrm{M} \mathrm{NaOH}$.

\begin{tabular}{lc}
\hline Experimental solution & Limiting current $(\mathrm{A})$ \\
\hline $\begin{array}{l}\text { Wet industrial phosphoric acid diluted at } \\
5 \%(\mathrm{w} / \mathrm{w})\end{array}$ & indeterminate \\
$\begin{array}{l}\text { Wet industrial phosphoric acid diluted at } \\
1 \%(\mathrm{w} / \mathrm{w})\end{array}$ & indeterminate \\
Solution of $6.27 \mathrm{~g} / \mathrm{L}$ of $\mathrm{NaCl}$ and $54 \%$ & 0.20 \\
$\begin{array}{l}\text { analytical-grade phosphoric acid diluted } \\
\text { at } 5 \%(\mathrm{w} / \mathrm{w})\end{array}$ & \\
$\begin{array}{l}\text { Solution of } 1.254 \mathrm{~g} / \mathrm{L} \text { of } \mathrm{NaCl} \text { and } \\
\text { analytical-grade phosphoric acid diluted }\end{array}$ & 0.15 \\
at $1 \%(\mathrm{w} / \mathrm{w})$ & \\
\hline
\end{tabular}

${ }^{*} 0.15 \mathrm{~A}$ was the average current level during the electrodialysis process.

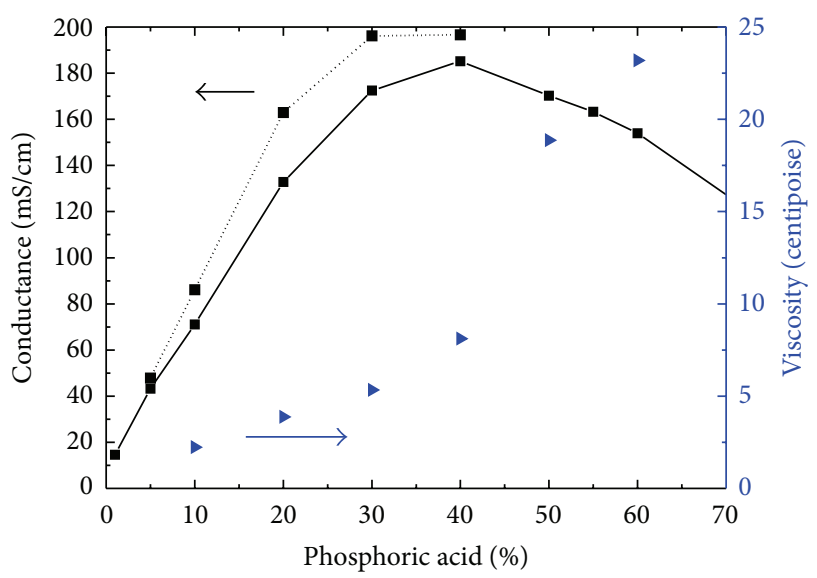

FIGURE 3: Conductance values for industrial phosphoric acid (- - - -) and analytical-grade phosphoric acid (-); phosphoric acid viscosity data $(\bullet)$, as reported by Lobo [39].

The electrical resistances of the solution are discussed first. The solution of $\mathrm{NaCl}$ in the analytical-grade acid produced the highest electrical current. This behavior was observed because the sodium and chlorine ions were moving faster than the metal-phosphate complexes. More precisely, the motion of these ions was unimpeded by attachment to phosphates. Metals, such as aluminum, would have to drag their phosphate ligands along, resulting in a high electrical resistance for the complex. Similar results were obtained by Diallo et al. [43], who observed that the electrophoretic mobility of ions was proportional to the ion charge/size ratio. Diallo et al. [43] observed that ion mobility in an electric field range could be ranked in descending order as follows: $\mathrm{Cl}^{-}>\mathrm{H}_{2} \mathrm{PO}_{4}{ }^{-}>\mathrm{H}_{3} \mathrm{PO}_{4}{ }^{0}>\mathrm{Fe}\left(\mathrm{H}_{2} \mathrm{PO}_{4}\right)_{4}{ }^{-}$. Therefore, the complexes decreased the electrostatic interactions resulting in a low electrical current (Figure 4). The phosphate-free ions (see Figures 2(b) and 2(c)) had more mobility than the acids (Figure 2(a)) and the metal-phosphate complexes (Figure 2(d)). The membranes electrical resistances are discussed next. Pismenskaya et al. $[44,45]$ reported a low electrical conductivity for an anionic-exchange membrane in contact with a phosphate solution. Koter and Kultys [46] 


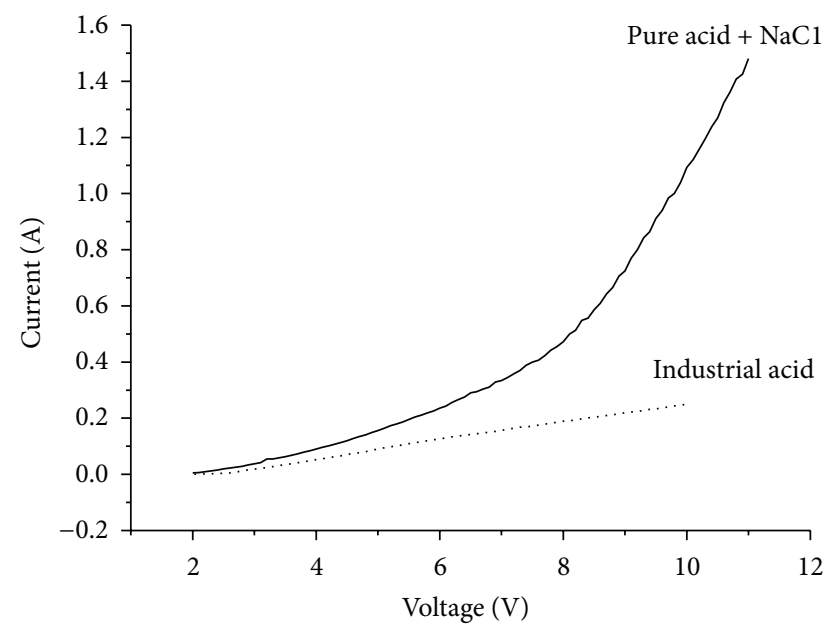

FIGURE 4: Current-potential curves for the electrodialysis cell at a flow rate of $5 \mathrm{~L} / \mathrm{min}$ for industrial phosphoric acid (- - -) and analytical-grade phosphoric acid with $6.27 \mathrm{~g} / \mathrm{L} \mathrm{NaCl}(-)$.

observed a low efficiency for phosphoric acid removal by electrodialysis with anionic membranes. Koter and Kultys [46] theoretically calculated an association equilibrium constant between $\mathrm{H}_{2} \mathrm{PO}_{4}{ }^{-}$and the fixed charges of the anionic membrane. This association diminished the efficacy of the separation process because the $\mathrm{H}_{2} \mathrm{PO}_{4}{ }^{-}$neutralized the fixed charges in the anionic membrane. In a previous study, we observed a similar association between nitrate ions and the fixed charges in an anionic membrane using Raman spectroscopy and electrochemical impedance spectroscopy [34]. The excessive potential drop across the cation exchange membrane was because only the protons and the phosphatefree cations were able to migrate effectively. The metalphosphate complexes had large ionic radii and low charge densities, which decreased their electrostatic interactions and mobilities inside the membrane. This increase of the electrical resistance was explained in Section 3.1. The speciation diagrams clearly show that most positive ions migrated with a very low efficiency because of their reduced ionic charge. However, proton transfer across the membrane increased at the highest electrical currents, depleting the proton concentrations inside the membrane. Therefore, the internal membrane resistance increased.

3.3. Demineralization of Industrial- and Analytical-Grade Acids. The conductance of the acids decreased during the electrodialysis process, as shown in Figure 5. The $\mathrm{pH}$ decreased slightly during the demineralization, while the temperature increased by $10^{\circ} \mathrm{C}$. These changes did not alter the chemical composition of the solutions and the transport of ions was negligibly affected by the small temperature change.

Hannachi et al. [15] observed that the highest cation removal occurred for the $\mathrm{Mg}^{2+}$ species; see Table 1. This result is supported by the speciation diagrams (Figure 2), which clearly show that the $\mathrm{Mg}^{2+}$ and phosphate can migrate independently of each other. It is known that $\mathrm{Mg}^{2+}$ and phosphate do not form a covalent complex; for example, Raman
TABLE 5: Ion concentrations in the central compartment before and after demineralization for $450 \mathrm{~min}$; the cell potential was approximately $7.4 \mathrm{~V}$ and the average electric current was was $0.15 \mathrm{~A}$.

\begin{tabular}{lccc}
\hline \multicolumn{2}{c}{ Initial concentration } & \multicolumn{2}{c}{ Final concentration } \\
$\mathrm{MgO}$ & $\mathrm{H}_{3} \mathrm{PO}_{4}$ & $\mathrm{MgO}$ & $\mathrm{H}_{3} \mathrm{PO}_{4}$ \\
\hline $0.0192 \mathrm{M}$ & $0.707 \mathrm{M}$ & $0.0072 \mathrm{M}$ & $0.206 \mathrm{M}$ \\
\hline
\end{tabular}

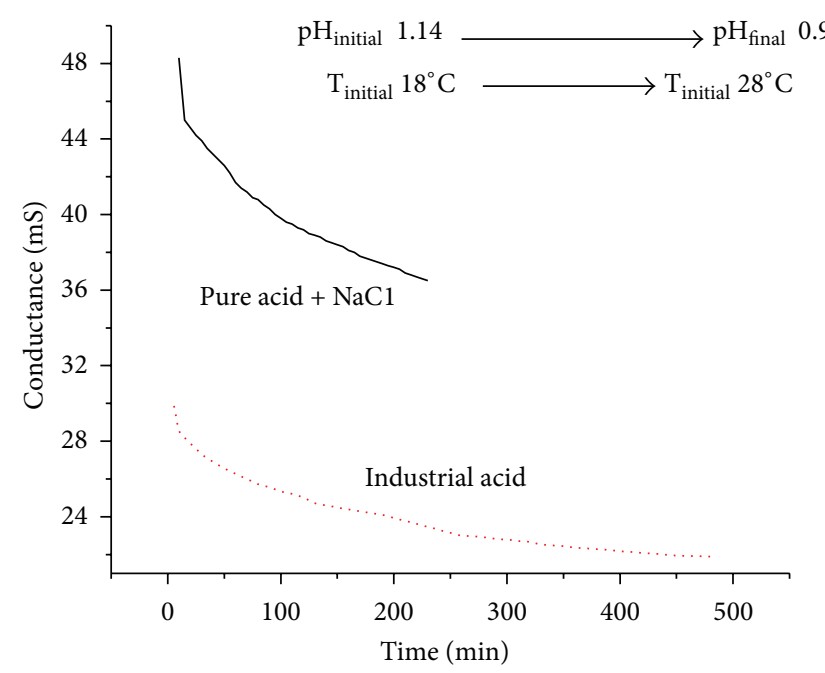

FIGURE 5: Variation in the conductance of the central compartment during electrodialysis; a constant electrical current of $0.15 \mathrm{~A}$ was applied to the conventional electrodialysis cell containing industrial phosphoric acid at $5 \%(-)$ and analytical-grade phosphoric acid at $5 \%$ with $6.27 \mathrm{~g} / \mathrm{L} \mathrm{NaCl} \mathrm{(-} \mathrm{-} \mathrm{-} \mathrm{);} \mathrm{the} \mathrm{initial} \mathrm{and} \mathrm{final} \mathrm{temperatures} \mathrm{and}$ $\mathrm{pH}$ values are also reported.

spectroscopy has been used to show that the intermolecular $\mathrm{Mg}-\mathrm{O}-\mathrm{P}$ bonding in phosphate salts is more ionic than for other metal-O-P bonds [47]. These ions were selected as a representative species to determine the electrodialysis efficiency. The initial and final concentrations of these species are listed in Table 5. The $\mathrm{Mg}^{2+}$ concentration decreased by approximately $63 \%$ on average of its initial value, whereas approximately $70 \%$ of the phosphates migrated, which was more than expected. However, the ratio between the concentration of the $\mathrm{Mg}^{2+}$ ions and that of the phosphoric acid was the same before and after the demineralization process (see Figure 6). The same behavior was observed for the ratio between the concentration of the $\mathrm{Na}^{+}$ions and that of the analytical-grade phosphoric acid. These results show that electrodialysis cannot be used to purify the acid in the central compartment. The migration of phosphates could produce a highly concentrated phosphoric acid solution in the anolyte; however, the sulfates and chlorides would also migrate. Consequently, electrodialysis would produce an anolyte solution containing anionic impurities. The low migration of free cations could be used to produce a catholyte containing cationic impurities.

The energy consumed in the migration of the $\mathrm{Na}^{+}$and $\mathrm{Cl}^{-}$species was compared with the energy consumption for the electrodialysis of the industrial-grade acid (see Table 6). 
TABLE 6: Energy consumption of the electrodialysis cell ${ }^{*}$.

\begin{tabular}{lc}
\hline Process characteristics & Energy \\
\hline The central compartment contained a $0.1 \mathrm{M} \mathrm{NaCl}$ & \\
solution in $5 \%$ analytical-grade phosphoric acid & \\
The cell current was constant at $0.2 \mathrm{~A}$, and the & \\
average potential was $8.5 \mathrm{~V}$. The $\mathrm{NaCl}$ was diluted & $1.57 \mathrm{kWh} / \mathrm{kg}$ \\
from $6.27 \mathrm{~g}$ to $1.03 \mathrm{~g}$ and approximately $40 \%$ of the & \\
acid was removed & \\
\hline
\end{tabular}

The central compartment contained

industrial-grade phosphoric acid. The cell current

was constant at $0.2 \mathrm{~A}$, and potential was

approximately $8.8 \mathrm{~V}$

The concentration changes are reported in Table 5

${ }^{*}$ The volume of the feed tank was $10 \mathrm{~L}$. The flow rate was at $5 \mathrm{Lmin}^{-1}$; average temperature was $24 \pm 2^{\circ} \mathrm{C}$. The duration of the experiment was $230 \mathrm{~min}$.

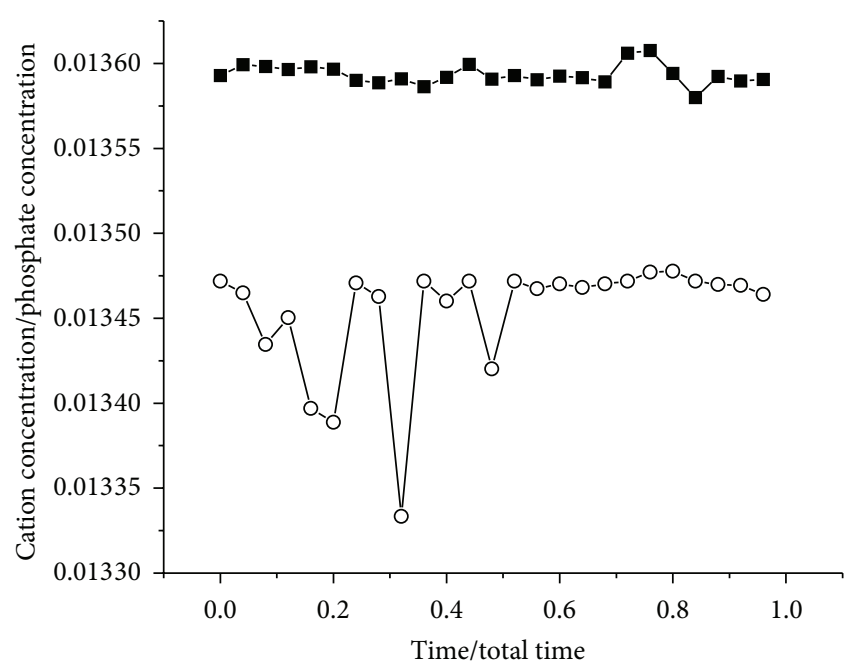

FIGURE 6: The ratio between the concentration of $\mathrm{Mg}^{2+}$ ions and that of $\mathrm{H}_{3} \mathrm{PO}_{4}$ acid (-m-) and the ratio between the concentration of $\mathrm{Na}^{+}$ions and that of $\mathrm{H}_{3} \mathrm{PO}_{4}$ acid (-O-O-) during the demineralization process.

The energy consumption for the migration of the $\mathrm{Na}^{+}$and $\mathrm{Cl}^{-}$ions was ten times more effective than the industrialgrade acid demineralization. That is, the energy consumed in $\mathrm{Cl}^{-}$migration $(1.57 \mathrm{kWh} / \mathrm{kg})$ was lower than the energy consumed in $\mathrm{H}_{2} \mathrm{PO}_{4}{ }^{-}$migration $(7.8 \mathrm{kWh} / \mathrm{kg}$ ). This result can be explained by the mass transfer limitations at low $\mathrm{H}_{2} \mathrm{PO}_{4}{ }^{-}$ concentrations. The discussion on the electrical resistances of the solution and the membrane, which was previously presented in Section 3.2, can also explain this result.

There is insufficient energy consumption data to compare the studies in Table 1 with the present study. On the other hand, the data in Table 6 show that electrodialysis produced phosphoric acid concentrations that were similar to those reported by the studies in Table 2. Hanley et al. [20] reported lower energy consumption, and this author also reported a higher acid concentration than that was observed in the present study; but did not report the final concentration of impurities; see Table 2.
The energy consumption for the $\mathrm{Na}^{+}$and $\mathrm{Cl}^{-}$migration showed that the membranes performed acceptably for electrodialysis; however, the energy consumption for the industrial-grade acid showed that phosphate ions could not migrate efficiently across the membranes.

\section{Conclusions}

Many methods have been evaluated in the literature for the purification and concentration of merchant-grade phosphoric acid $\left(52 \% \mathrm{P}_{2} \mathrm{O}_{5}\right)$; see Table 1 . However, these methods cannot be ranked in terms of efficacy because speciation diagrams have not been considered. The speciation diagrams in this study showed that the formation of metal-phosphate complexes decreased electrostatic interactions because of the lower mobility of the complexes. This observation was in fair agreement with the electrodialysis results. The speciation diagrams predicted that the low resistance of sodium and chloride ions relative to the other ions can facilitate phosphoric acid removal, which was verified by the observed energy consumption in the electrodialysis process. The results of the studies in Tables 1 and 2 must be reexamined in light of the speciation diagrams that were constructed in the present work. For example, $\mathrm{Mg}^{2+}$ purification was higher than that for the other metal impurities as speciation diagrams predicted.

A dilute industrial phosphoric acid solution was used to prevent membrane fouling. The three-compartment cell produced a highly concentrated phosphoric acid solution with ionic impurities in the anolyte. In the central compartment, the acid concentration decreased without purifying the acid. Previous electrodialysis studies [20,21] have assumed that phosphate ions can efficiently migrate across membranes; however, our results show that such a migration process consumes a large amount of energy and would therefore be extremely costly. In addition, the voltages of the ED process were sufficient to damage the membrane. Our results show that electrodialysis is not commercially viable for purifying industrial-grade phosphoric acid. Nevertheless, in future research, our group will test another phosphate raw material, $\mathrm{Na}_{3} \mathrm{PO}_{4}$, by the electrodialysis technique, using this study as a benchmark.

\section{Acknowledgment}

The authors would like to acknowledge the financial support provided by Project from CONACYT (FOSIHGO 1999025008).

\section{References}

[1] G. Villalba, Y. Liu, H. Schroder, and R. U. Ayres, "Global phosphorus flows in the industrial economy from a production perspective," Journal of Industrial Ecology, vol. 12, no. 4, pp. 557569, 2008.

[2] M. Ghouse and H. Abaoud, "Materials used in the development of a $1 \mathrm{~kW}$ phospshoric acid fuel cell stack," Journal of New Materials for Electrochemical Systems, vol. 2, no. 3, pp. 201-206, 1999. 
[3] H.-Y. Kwak, H.-S. Lee, J.-Y. Jung, J.-S. Jeon, and D.-R. Park, "Exergetic and thermoeconomic analysis of a $200 \mathrm{~kW}$ phosphoric acid fuel cell plant," Fuel, vol. 83, no. 14-15, pp. 2087-2094, 2004.

[4] R. J. Kepfer and W. R. Devor, "Phosphoric acid purification," U.S. Patent 2,174,158, 1939.

[5] D. Goldstein, "Phosphoric acid purification," U.S. Patent 3,819,810, 1974.

[6] D. H. Michalski and V. Srinivasan, "Process of removing cationic impurities from wet process phosphoric acid," U.S. Patent 4,639,359, 1987.

[7] L. W. Bierman, M. L. Lopez, and J. E. Perkins, "Purification of phosphoric acid,” U.S. Patent: 4,877,594, 1989.

[8] A. I. Alonso, A. M. Urtiaga, S. Zamacona, A. Irabien, and I. Ortiz, "Kinetic modelling of cadmium removal from phosphoric acid by non-dispersive solvent extraction," Journal of Membrane Science, vol. 130, no. 1-2, pp. 193-203, 1997.

[9] H. F. T. Haraldsen, "Method for removal of heavy metals from phosphoric acid containing solutions," U.S. Patent 4,986,970, 1991.

[10] H. J. Skidmore and K. J. Hutter, "Methods of purifying phosphoric acid," U.S. Patent 5,945,000, 1999.

[11] L. H. Reyes, I. S. Medina, R. N. Mendoza, J. R. Vázquez, M. A. Rodríguez, and E. Guibal, "Extraction of cadmium from phosphoric acid using resins impregnated with organophosphorus extractants," Industrial and Engineering Chemistry Research, vol. 40, no. 5, pp. 1422-1433, 2001.

[12] M. P. González, R. Navarro, I. Saucedo, M. Avila, J. Revilla, and C. Bouchard, "Purification of phosphoric acid solutions by reverse osmosis and nanofiltration," Desalination, vol. 147, no. 1-3, pp. 315-320, 2002.

[13] K. Hotta and F. Kubota, "Method for purification of phosphoric acid high purity polyphosphoric acid," U.S. Patent: 6,861,039, 2005.

[14] M. P. González Muñoz, R. Navarro, I. Saucedo et al., "Hydrofluoric acid treatment for improved performance of a nanofiltration membrane," Desalination, vol. 191, no. 1-3, pp. 273-278, 2006.

[15] A. Hannachi, D. Habaili, C. Chtara, and A. Ratel, "Purification of wet process phosphoric acid by solvent extraction with TBP and MIBK mixtures," Separation and Purification Technology, vol. 55, no. 2, pp. 212-216, 2007.

[16] A. A. El-Asmy, H. M. Serag, M. A. Mahdy, and M. I. Amin, "Purification of phosphoric acid by minimizing iron, copper, cadmium and fluoride," Separation and Purification Technology, vol. 61, no. 3, pp. 287-292, 2008.

[17] K. Ishikawa, K. Yokoi, K. Takeuchi, Y. Kurita, and H. Uchiyama, "High purity phosphoric acid and process of producing the same," U.S. Patent: 7,470,414,B2, 2008.

[18] M. I. Amin, M. M. Ali, H. M. Kamal, A. M. Youssef, and M. A. Akl, "Recovery of high grade phosphoric acid from wet process acid by solvent extraction with aliphatic alcohols," Hydrometallurgy, vol. 105, no. 1-2, pp. 115-119, 2010.

[19] K. W. Loest and J. T. Schaefer, "Production of monobasic potassium phosphate by electrodialysis," US Patent: 4,033,842, 1977.

[20] T. R. Hanley, H.-K. Chiu, and R. J. Urban, "Phosphoric acid concentration by electrodialysis," AIChE Symposium Series, vol. 82, pp. 121-132, 1986.
[21] D. Touaibia, H. Kerdjoudj, and A. T. Cherif, "Concentration and purification of wet industrial phosphoric acid by electroelectrodialysis," Journal of Applied Electrochemistry, vol. 26, no. 10, pp. 1071-1073, 1996.

[22] S. A. Ueda, "Method for purifying phosphoric acid," Japanese Patent Kokai No. Sho 48 [1973]-10312, 1973.

[23] M. B. C. Elleuch, M. B. Amor, and G. Pourcelly, "Phosphoric acid purification by a membrane process: electrodeionization on ion-exchange textiles," Separation and Purification Technology, vol. 51, no. 3, pp. 285-290, 2006.

[24] Y. K. Litsis and B. A. Popov, "Method of extraction of phosphoric acid," Russian Inventor's Certification No.443839, 1974.

[25] T. Yamabe, "Method for the manufacture of phosphoric acid," Japanese Patent Kokai No. Sho 48 [1976]-106696, 1976.

[26] T. Yoshihara, "A method for refining phosphoric acid," Japanese Patent Kokai No. Sho 53 [1978]-96994, 1978.

[27] K. Moeglich, "Electrochemical processes utilizing layered membrane electrochemical processes utilizing layered membrane," U.S. Patent 4,326,935, 1982.

[28] P. Długołecki, K. Nymeijer, S. Metz, and M. Wessling, "Current status of ion exchange membranes for power generation from salinity gradients," Journal of Membrane Science, vol. 319, no. 12, pp. 214-222, 2008.

[29] E. Högfeldt, Stability Constants of Metal-Ion Complexes. Part A: Inorganic Ligands, vol. 21 of IUPAC Chemical Data Series, Pergamon Press, 1982.

[30] D. D. Perrin, Dissociation Constants of Inorganic Acids and Bases in Aqueous Solution, IUPAC, Butterworths, London, UK, 1969.

[31] A. E. Martell and R. M. Smith, Critical Stability Constants, vol. 4 of Inorganic Complexes, Plenum Press, New York, NY, USA, 1976.

[32] J. N. Butler, Ionic Equilibrium: Solubility and PH Calculations, John Wiley \& Sons, Toronto, Canada, 1998.

[33] T. S. Sorensen, Interfacial Electrodynamics of Membranes and Polymer Films, in Surface Chemistry and Electrochemistry of Membranes, CRC Press, New York, NY, USA, 1999.

[34] U. López-García, R. Antaño-López, G. Orozco, T. Chapman, and F. Castaneda, "Characterization of electrodialysis membranes by electrochemical impedance spectroscopy at low polarization and by Raman spectroscopy," Separation and Purification Technology, vol. 68, no. 3, pp. 375-381, 2009.

[35] D. R. Migneault and R. K. Forcé, "Dissociation constants of phosphoric acid at $25^{\circ} \mathrm{C}$ and the ion pairing of sodium with orthophosphate ligands at $25^{\circ}$ C," Journal of Solution Chemistry, vol. 17, no. 10, pp. 987-997, 1988.

[36] A. D. Pethybridge, J. D. R. Talbot, and W. A. House, "Precise conductance measurements on dilute aqueous solutions of sodium and potassium hydrogenphosphate and dihydrogenphosphate," Journal of Solution Chemistry, vol. 35, no. 3, pp. 381393, 2006.

[37] I. Puigdomenech, Make Equilibrium Diagrams Using Sophisticated Algorithms (MEDUSA), Inorganic Chemistry, Royal Institute of Technology, Stockholm, Sweden, 2004.

[38] M. Azaroual, C. Kervevan, A. Lassin et al., "Thermo-kinetic and physico-chemical modeling of processes generating scaling problems in phosphoric acid and fertilizers production industries," Procedia Engineering, vol. 46, pp. 68-675, 2012.

[39] V. M. M. Lobo, Handbook of Electrolyte Solutions, Part A. Physical, vol. 41 of Sciences Data, Elsevier Science, New York, NY, USA, 1989. 
[40] F. A. Cotton and G. Wilkinson, Química Inorgánica Avanzada, Limusa, Cancun, Mexico, 1st edition, 1993.

[41] M. Cherif, A. Mgaidi, N. Ammar, G. Vallée, and W. Fürst, "A new investigation of aqueous orthophosphoric acid speciation using Raman spectroscopy," Journal of Solution Chemistry, vol. 29, no. 3, pp. 255-269, 2000.

[42] W. W. Rudolph, "Raman-spectroscopic measurements of the first dissociation constant of aqueous phosphoric acid solution from 5 to $301^{\circ}$ C," Journal of Solution Chemistry, vol. 41, no. 4, pp. 630-645, 2012.

[43] H. Diallo, M. Rabiller-Baudry, K. Khaless, and B. Chaufer, "On the electrostatic interactions in the transfer mechanisms of iron during nanofiltration in high concentrated phosphoric acid," Journal of Membrane Science, vol. 427, pp. 37-47, 2013.

[44] N. Pismenskaya, E. Laktionov, V. Nikonenko, A. El Attar, B. Auclair, and G. Pourcelly, "Dependence of composition of anion-exchange membranes and their electrical conductivity on concentration of sodium salts of carbonic and phosphoric acids," Journal of Membrane Science, vol. 181, no. 2, pp. 185-197, 2001.

[45] N. Pismenskaya, V. Nikonenko, B. Auclair, and G. Pourcelly, "Transport of weak-electrolyte anions through anion exchange membranes: Current-voltage characteristics," Journal of Membrane Science, vol. 189, no. 1, pp. 129-140, 2001.

[46] S. Koter and M. Kultys, "Modeling the electric transport of sulfuric and phosphoric acids through anion-exchange membranes," Separation and Purification Technology, vol. 73, no. 2, pp. 219-229, 2010.

[47] V. Koleva and V. Stefov, "Phosphate ion vibrations in dihydrogen phosphate salts of the type $\mathrm{M}\left(\mathrm{H}_{2} \mathrm{PO}_{4}\right) 2 \cdot 2 \mathrm{H}_{2} \mathrm{O}(\mathrm{M}=\mathrm{Mg}$, $\mathrm{Mn}, \mathrm{Co}, \mathrm{Ni}, \mathrm{Zn}, \mathrm{Cd})$ : Spectra-structure correlate," Vibrational Spectroscopy, vol. 64, pp. 89-100, 2013. 

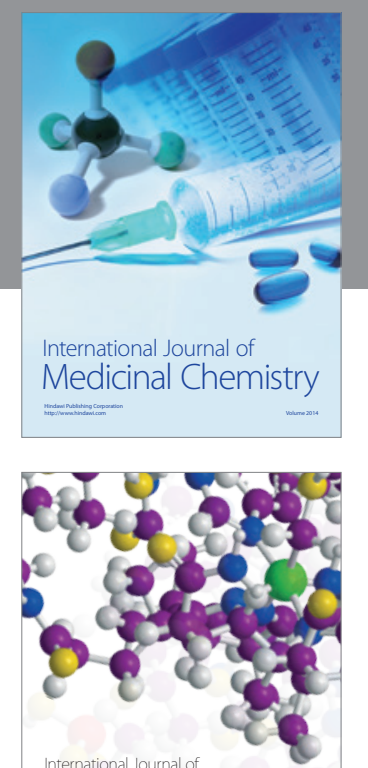

\section{Carbohydrate} Chemistry

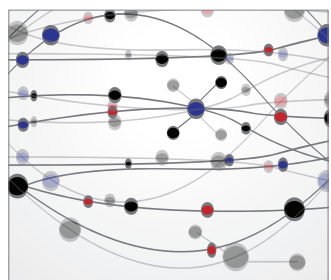

The Scientific World Journal
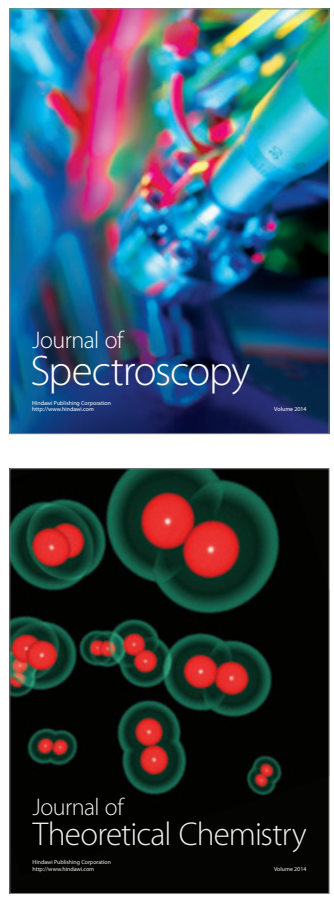
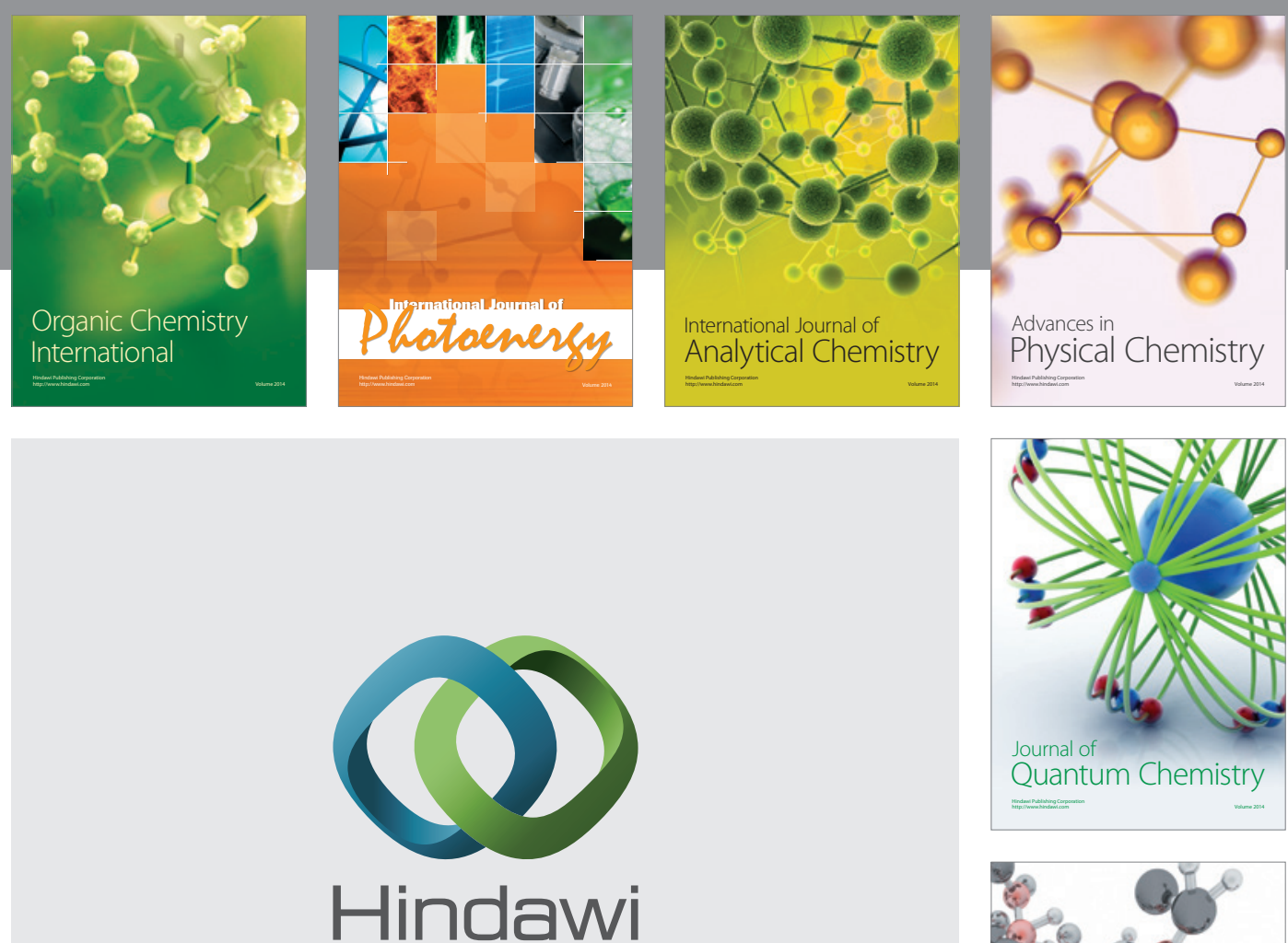

Submit your manuscripts at

http://www.hindawi.com

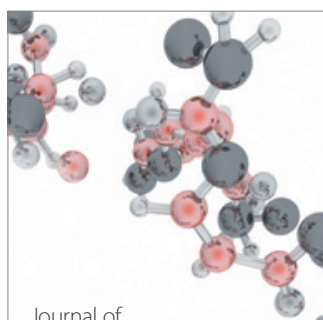

Analytical Methods

in Chemistry

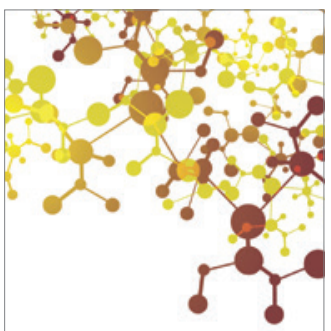

Journal of

Applied Chemistry

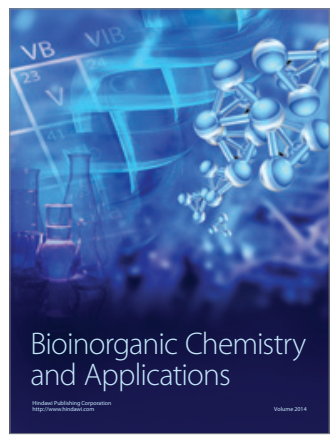

Inorganic Chemistry
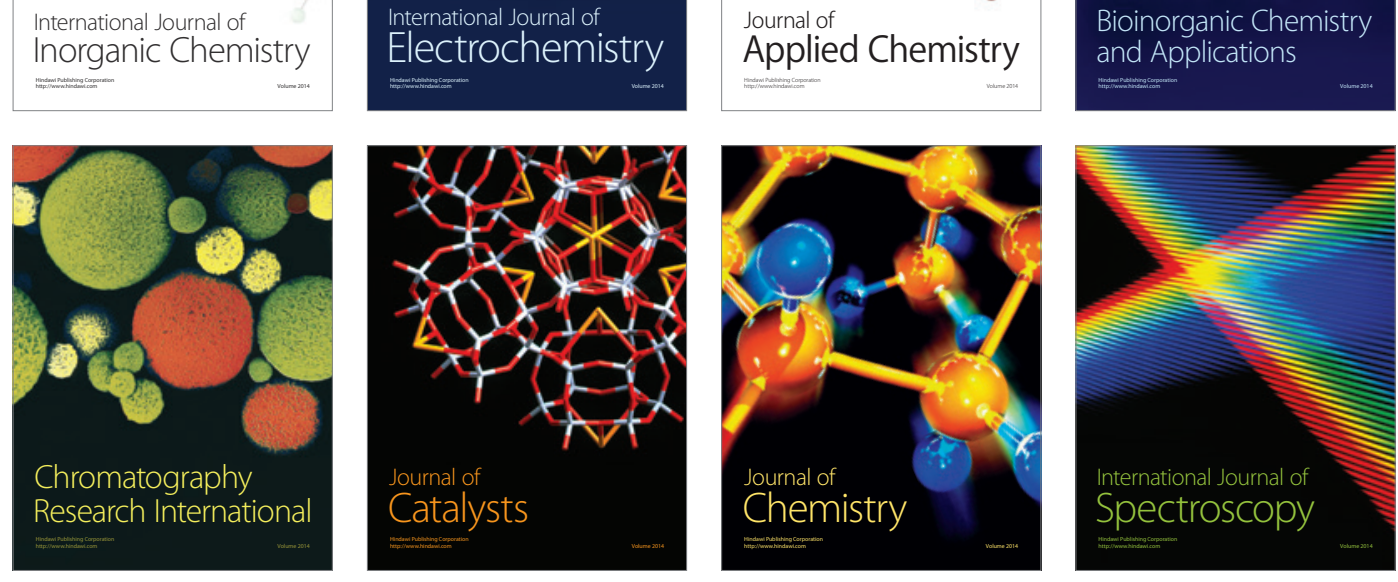